\title{
Focusing The Mediating Role Of Knowledge Management Practices: How Does Institutional And Interpersonal Trust Support Exploitative And Exploratory Innovation? \\ Sarra Berraies, ISIG Kairouan, Tunisia \\ Maha Achour, ISIG Kairouan, Tunisia \\ Mehrez Chaher, ISG Tunis, Tunisia
}

\begin{abstract}
The purpose of this paper is to investigate the influence of both institutional and interpersonal trust on innovation and deepens the analysis by exploring the mediating role of knowledge management (KM) practices in this relationship. Conceptually, this reflection leads to the proposal of a conceptual model summarizing the relationships between the research variables. This model was tested with 226 senior officials in companies operating in the information and communication technologies (ICT) Tunisian sector on the basis of a structured questionnaire. The collected data were treated by structural equation analysis using AMOS software. The results of the empirical study highlighted the significant relationship between interpersonal trust and innovation and confirmed that KM practices act as partial mediators in this relationship. Findings show also that institutional trust is not correlated to KM practices and to innovation.
\end{abstract}

Keywords: Trust; Knowledge Management; Innovation

\section{INTRODUCTION}

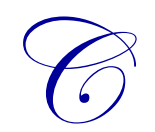

ompanies are facing today to a highly competitive environment and an economic and social crisis. In this context, they are called to reconsider their management methods and to explore new ways allowing them to innovate. In fact, the context of crisis could even offer companies the opportunity to challenge and embark upon new areas of innovation. In this perspective, considerable research has focused on the critical role of innovation as a survival and competitive advantage factor for companies (Drucker, 1985; Porter, 1986), particularly in a context of crisis (Naidoo, 2010). This innovative capability feeds on different forms of knowledge that companies absorb at all phases of their development and also by seeking and exploiting learning opportunities that their environment integrates. In this regard, Nonaka \& Takeuchi (1995) provided evidence that innovation is based on the creation of new knowledge. In this sense, the idea put forward in this research is that in the context of today's knowledge-based economy, the integration of knowledge management (KM) practices in organizations becomes imperative to each company in order to exploit knowledge flows, as a source of innovation.

Despite a rich literature on $\mathrm{KM}$ and innovation, the relationship between these variables remains controversial. Considerable research pointed out that the relationship between these variables depends on certain conditions which seek to create an enabling environment for knowledge development (Nonaka \& Takeuchi, 1995; Nonaka et al., 2000). It would be therefore interesting to identify the factors affecting the successful implementation of KM and its contribution to innovation. In particular, the success of the KM is enhanced by the establishment of a climate of trust into the organizations (Davenport \& Prusak, 1998; Lee \& Choi, 2003; Nonaka \& Takeuchi, 1995). 
In particular, interpersonal trust is an important condition for the creation and sharing of explicit and tacit knowledge (Nonaka et al., 2000). By trusting each other, employees can accept to share their knowledge and cross the cognitive distance between them. Moreover, trust increases the probability that people understand the absorbed knowledge from others and implement it into practices (Abrams et al., 2003). The role of interpersonal trust as a lever for creating and sharing knowledge is especially important in the context of Arab cultures. Hutchings \& Weir (2005) argue that in Arab countries, interpersonal trust is a crucial precondition for knowledge sharing between employees. Furthermore, Golipour et al. (2011) emphasize that innovation is based on the intensity of social relations within the company, which guarantees to employees and organization the access to a wide range of knowledge. These relationships are dependent in turns of the degree of trust between employees, which increases their predisposition to take risks and leads to greater creativity and innovation (Golipour et al., 2011). Moreover, another type of trust namely institutional trust is also pointed out as a key factor that creates an enabling organizational environment for knowledge sharing and innovation (Ford, 2003; Ellonen et al., 2008). In line with this, we analyze the effect of both interpersonal and institutional trust as key ingredients for exploitative and exploratory innovation as well as the mediator role of KM practices in this relationship. This study aims to provide a better understanding about how these types of trust may affect KM practices and innovation and to deal with this topic both theoretically and within information and communication technologies (ICT) Tunisian companies.

This paper is organized as follows. First, we analyze the theoretical background related to the research variables. Then, we conclude our analysis by developing a research model summarizing the causal relationships between these variables. Finally, we present the results of our empirical investigation while highlighting managerial implications, limitations and perspectives of this research.

\section{LITERATURE REVIEW}

\subsection{Knowledge Management Practices}

Knowledge management aims to encourage employees to share their knowledge by building an enabling environment for absorption, organization and share of knowledge within companies (Martinez, 1998). It is a set of proactive activities that allows the identification, preservation and shaping of knowledge to make it understandable and to facilitate its transmission to organizational members (Berraies, 2012). This definition aligns itself with those of several authors by presenting the KM as a set of activities which aims to support an organization in upgrading its knowledge-related assets. In this line, Bassie (1997) identified three activities underlying the concept of KM, namely creation, capture and use of knowledge. For Davenport (1994), KM represents a process of capture, distribution and use of knowledge. Lee et al. (2004), for their part, have defined KM as the creation, accumulation, sharing, utilization and internalization of knowledge.

In this paper, we refer to Darroch (2003) to define KM as knowledge acquisition, knowledge dissemination and responsiveness to knowledge. Knowledge acquisition means "the location, creation or discovery of knowledge" (Darroch, 2003). It relates to the absorption of a wide range of new knowledge from internal or external sources. Knowledge could be absorbed through the internal interactions between individuals within the company, but also by the interaction of the company with its various stakeholders. Knowledge acquisition refers also to the development of new knowledge by acquiring tacit knowledge and converting and structuring this type of knowledge to an explicit form (Nemani, 2010).

Dissemination of knowledge materializes the knowledge transfer to all organizational members. It is illustrated according to Darroch (2003) by the 'spiral of knowledge creation' conceptualized by Nonaka (1991) and Nonaka \& Takeuchi (1995). These latter authors investigated several Japanese companies that have demonstrated success as catalysts for innovation. According to the Japanese theory, the transfer of knowledge created is based on both an ontological dimension, centered on the fact that knowledge is a matter of human being and is built at the individual, group and organizational levels and an epistemological dimension that incorporates interaction between tacit and explicit knowledge. To disseminate knowledge, it is important to continuously feed the knowledge base of the company by performing capitalization of experiences feedback and best practices and explicit formulation of tacit knowledge in order to benefit to all organizational members. Knowledge may particularly be channeled through 
ICT, databases, meetings, mentoring, staff rotation, brainstorming or collaborative workspaces (Nonaka \& Takeuchi, 1995; Nonaka et al., 2000).

Once knowledge has been disseminated to members of the organization, it must be effectively exploited and not be placed in 'drawers'. In this line, responsiveness to knowledge represents a third activity integrating KM which means according to Darroch (2003) that "the organization responds to the various types of knowledge it has access to". Knowledge stored in the form of documents, procedure manuals and computerized databases allows to avoid repeating work already done or wasting time thinking about a problem already solved and make use of the 'best practices' resulting from previous experiences. In the same vein, absorbed knowledge permits to the organization to react to changes about consumers, competitors and technologies and to reshape continuously their strategies and procedures (Darroch, 2003). For example, Knowledge absorbed through interaction with customers is likely to enable the company to respond to their needs by designing products that are valued by them.

\subsection{Effect of Trust on KM Practices}

Trust has been conceptualized in various ways. A literature review shows that research interested in this concept falls into two main perspectives: psychological and behavioral perspectives (Chouk \& Perrien, 2003; Robinson, 1996). From a psychological perspective, trust is seen as a psychological state that incorporates assumptions, beliefs or positive expectations that one expected in another party's behavior, and is situated "upstream of behavioral intention" (Chouk \& Perrien, 2003). Following a behavioral approach, trust is understood as a trusting behavior (Chouk \& Perrien, 2003) or a willingness to be vulnerable and to rely on another person (Mayer et al, 1995; Rousseau et al., 1998). In addition, trust is identified by many researchers as a multidimensional concept consisting of cognitive and emotional elements (McAllister, 1995; Mayer et al., 1995). Mayer et al. (1995) associate trust to an individual's traits namely his degree of integrity, competence and benevolence which establish whether he can rely on someone else or not.

Several types of trust have been highlighted in the literature, especially interpersonal and institutional trust. Interpersonal trust, describes the relationship between co-workers (horizontal trust) or between an employee and his supervisor (Vertical trust) (Ellonen et al., 2008). It refers to feeling of confidence that one person has for another person. As for institutional trust, it is defined by these authors as the trust of the members of an organization "in its vision and strategy, commercial and technological competence, its appropriate processes and structures as well as its human resources policies" (Ellonen et al., 2008). This impersonal form of trust refers to the feeling of confidence of an individual conferred by the fair and efficient systems of organizations (Ford, 2003). In this paper, we have chosen to focus on the effect of these forms of trust on KM practices.

A literature review shows that several authors agree that trust is a key success of KM (Davenport \& Prusak, 1998; Lee \& Choi, 2003; Nonaka \& Takeuchi, 1995). Indeed, interpersonal trust is an element which determines the relationships between individuals, the continuity of these relationships and their willingness to share with others their own knowledge. As for institutional trust, it is "increasingly important for knowledge based organizations" (Pöyhönen \& Blomqvist, 2006). Furthermore, trust influences the intensity of KM practices (Sankowska, 2013). This statement becomes even more relevant in Arab countries like Tunisia where a culture of trust within companies determines the success of such activities (Hutchings \& Weir, 2005).

Particularly, institutional trust is identified as a key factor for knowledge acquisition and dissemination (Bugdol \& Jedynak, 2015; Ford, 2003). Indeed, a high level of institutional trust within organizations is likely to promote employees engagement (Marais \& Hofmeyr, 2013), which in turn will lead them to make more effort to share their knowledge and to absorb relevant knowledge from the other employees or from external sources for the benefit of the company. Ford (2003) emphasizes the importance of both interpersonal and institutional trust in promoting KM processes namely acquisition, creation, codification, transfer and use of knowledge. She supports the idea that the presence of distrust will constitute a barrier for the KM practices within companies (Ford, 2003).

Moreover, Davenport \& Prusak (1998), Ellonen et al. (2008) and Probst et al. (2000) point out that interpersonal trust, between co-workers and between employees and their supervisors, has a positive effect on knowledge acquisition and knowledge dissemination. These KM practices that are built through interaction of 
individuals are based on mutual trust relationships (Morgan \& Hunt, 1994; Ribiere \& Tuggle, 2005). Moreover, the volume of useful knowledge absorbed is proportional to the trust between individuals (Upadhayayula \& Kumar, 2004). Interpersonal trust also affects the understanding and assimilation of absorbed knowledge (Abrams et al., 2003). According to Darroch (2005), knowledge acquisition is made possible through, among other things, the identification of employees' opinions and feelings. The latter are more willing to share their own tacit knowledge and generate new knowledge if they can rely on others (Ngah et al., 2008). Indeed, individuals may feel deprived of some power by unveiling their tacit knowledge. In an atmosphere of no trust, people will tend to concentrate on themselves and protect their valuable knowledge (Sankowska, 2013). Thus, interpersonal trust is a social prerequisite for externalizing this type of knowledge (Lamari, 2010). However, in the context of the empirical study conducted in Singapore, Hoe \& McShane (2002) found a non-significant relationship between interpersonal trust and knowledge acquisition and dissemination. It is therefore important from these controversies to empirically test these relationships.

As for the relationship between trust and knowledge use, Ford (2003) stresses that the presence of both institutional and interpersonal trust between an employee and his supervisor (vertical trust) has an effect on knowledge use and application. Creating a trustful institutional environment within companies is an enabling factor to make employees use the knowledge they have acquired for the benefit of the organization. Furthermore, Holste \& Fields (2010) point out that horizontal trust strongly influence the willingness of employees to share and to use tacit knowledge. Indeed, as we mentioned above, according to the definition of Mayer et al. (1995), trust is based both on the integrity, benevolence and competence. The latter type of trust namely the trust based on competence materializes that a person believes that another person has the required knowledge in relation to a particular area. Therefore, if an individual perceived that the other person is credible and competent, he will be more willing to use knowledge acquired from the latter (Holste \& Fields, 2010; Szulanski, 1995).

Hence, we propose the following hypotheses:

Hypothesis 1a: Horizontal trust has a positive effect on KM practices.

Hypothesis 1b: Vertical trust has a positive effect on KM practices.

Hypothesis 1c: Institutional trust has a positive effect on KM practices.

\subsection{Effect of KM Practices on Innovation}

An analysis of the literature suggests that the concept of innovation has changed. It is no longer considered as the result of an individual intelligence within the meaning of the entrepreneur-innovator of Schumpeter (1982), but as the result of a collective intelligence (Kline \& Rosenberg, 1986; Nonaka \& Takeuchi, 1995). In addition, innovation is no longer treated as a simple result but also as a dynamic process of knowledge and skills management (Jansen et al., 2006; Nonaka \& Takeuchi, 1995). Moreover, Deroy (2004) aptly points out that successful innovation nowadays depends on an approach that is rational based on key success factors but also that gives way for some contingency. Indeed, even if we cannot imagine the innovation as a fortuitous process, too much formalism can constitute a barrier to the uniqueness that characterizes innovation. At this level, March (1991) argues that to innovate, a company should both use the skills it has but also try to look for new skills. Accordingly, the author has identified two types of innovation: exploitative innovation and exploratory innovation. The same idea was discussed by Benner \& Tushman (2003) and Jansen et al. (2006).

Exploitative innovations are based on the existing companies' resources and are represented by small improvements in methods, technologies or products. They feed on best practices and routines generated in the past. This type of innovation is called incremental innovation which is designed for existing customers or markets (Jansen et al., 2006). In an environment characterized by an intense competition, companies can no longer rely only on what they can do. They should challenge what they already know and explore new opportunities. In this regard, Nonaka \& Takeuchi (1995) speaks of 'creative chaos', where the company abandons routines and rebuilds them by conceiving differently reality. It is in this sense that exploratory innovation is based on the implementation of new knowledge and is intended for new customers and markets (Jansen et al, 2006). Authors such as Benner \& Tushman 
(2003) and March (1991) note that business survival depends on a right balance between these two types of innovations. For Benner \& Tushman (2003), the most successful firms are ambidextrous firms that found a balance between continuous innovation focused on existing resources and the search for new knowledge.

In fact, the literature has shown that several authors claim that KM affects innovation (Jansen et al, 2006; Nonaka \& Takeuchi, 1995). Martinet (2003) assimilates innovation strategies to the process of organizational knowledge creation. Miller \& Morris (1999) point out that innovation success has its germs in the explanation of tacit knowledge. The relationship between KM and business innovation has been particularly established by Nonaka \& Takeuchi (1995) who highlighted how KM practices can absorb, create and disseminate knowledge, both tacit and explicit, from internal and external sources, to integrate them into a new concept of product or service. Allameh \& Abbas (2010), Darroch (2005) and Ramirez \& Kumpikaite (2012) found a positive relationship between knowledge management practices and innovation. Nonaka \& Takeuchi (1995) have shown that the generation and dissemination of new knowledge are catalysts for innovation. These authors argue that explanation of tacit knowledge, made possible by social interactions, promotes the generation of 'original' ideas, which are the basis for radical innovations. Indeed, interaction with stakeholders allows the company to absorb strategic knowledge and always makes it on the lookout for new products on the market. Particularly, knowledge absorption through interaction with customers is likely to enable the company to know their expectations and even imagine a new product or service that can create value to them. Moreover, Schulze \& Hoegl (2008) point out that knowledge acquired and disseminated to organizational members allows the "'requisite variety' of perspectives of many people and the production of innovative ideas". Knowledge disseminated, henceforth profitable to all employees, is likely to enable them to identify new opportunities and leads to changes in behavior that result in actions to improve offer or to design new products or services (Darroch, 2005).

Bearing on these findings, we can assume that KM practices are catalysts for innovation. The aim of this study is to examine whether these practices lead to exploitative and / or exploratory innovation. In fact, revelation and use of new knowledge and the mastery of new skills that were ignored are likely to make up exploratory innovation emerge (Chanal \& Mothe, 2005; March, 1991). Meanwhile, Kitapci et al. (2012) established a significant relationship between the orientation of acquisition and use of knowledge and exploitative and exploratory innovations. Their work revealed however that the orientation of sharing and dissemination of knowledge does not affect exploitative nor exploratory innovations. Thus, we formulate the following hypothesis:

Hypothesis 2: KM practices have a positive effect on innovation.

\subsection{Effect of Trust on Innovation}

Trust is apprehended as a significant factor for developing social exchange and innovation (Ellonen et al., 2008; Golipour et al., 2011; Semerciöz et al., 2011). It promotes the intensity of social interactions that generates innovation (Golipour et al., 2011). Indeed, interactions between organizational members allow them to share knowledge and develop their skills and their innovative capabilities. These interactions may not nevertheless develop in the absence of trust between them. In reality, individuals accept the risk to share their knowledge with their colleagues, learn from each other and generate innovative ideas if they can rely on them. Abrams et al. (2003) argue in this sense that interpersonal trust is the basis of all creation and sharing of tacit knowledge particularly, which is an important source of innovation, mainly radical (Nonaka et al., 2000). Clegg et al. (2000), meanwhile, stressed that trust in others influences both the generation and implementation of innovative ideas. Moreover, Tan and Tan (2000) point out that employees' trust in their supervisor has a positive effect on their innovative behavior. For Golipour et al. (2011), employees who trust their superiors are more willing to get involved and to make efforts to develop new ideas. They tend to feel safe to take initiatives and explore new ways of doing things without fearing to be penalized by the employer in case of failure (Chandler et al., 2000). In the same vein, a high level of institutional trust is an enabling factor that makes employees feel safe to take risks and to generate new ideas which can be fructified into innovation (Dovey, 2009). Ellonen et al. (2008) emphasize that lateral trust, vertical trust and institutional trust are positively associated to organizational innovativeness. The same result was established by Semerciöz et al. (2011) who stressed particularly that among these three types of trust, institutional trust is the most important factor promoting organization's innovativeness. 
Moreover, organizational trust is a key factor that increases the willingness of employees to combine and use existing knowledge and also to explore new perspectives. Thus, it contributes to both exploitative and exploratory innovation (Tsai \& Ghoshal, 1998). In this regard, Gibson \& Birkinshaw (2004) point out that trust is positively correlated to organizational ambidexterity.

Therefore, we propose the following hypotheses:

Hypothesis 3a: Horizontal trust has a positive effect on innovation.

Hypothesis 3b: Vertical trust has a positive effect on innovation.

Hypothesis 3c: Institutional trust has a positive effect on innovation.

\subsection{Mediating role of KM practices}

Given the literature analysis performed, interpersonal trust (horizontal and vertical trust) and institutional trust prove to be factors that strongly influence KM practices, which in turn retroact positively on innovation. KM practices could thus play a mediating role to explain the link between these types of trust and innovation. Hence,

Hypothesis 4a: KM practices mediate the relationship between horizontal trust and innovation.

Hypothesis 4b: KM practices mediate the relationship between vertical trust and innovation.

Hypothesis 4c: KM practices mediate the relationship between institutional trust and innovation.

\subsection{Research model}

To assess the causal relationships between the research variables, we developed the conceptual model presented in Figure 1 below, which highlights that horizontal trust, vertical trust and institutional trust positively influence KM practices, which in turn have positive effects on exploitative and exploratory innovation.

Figure 1. Research Model

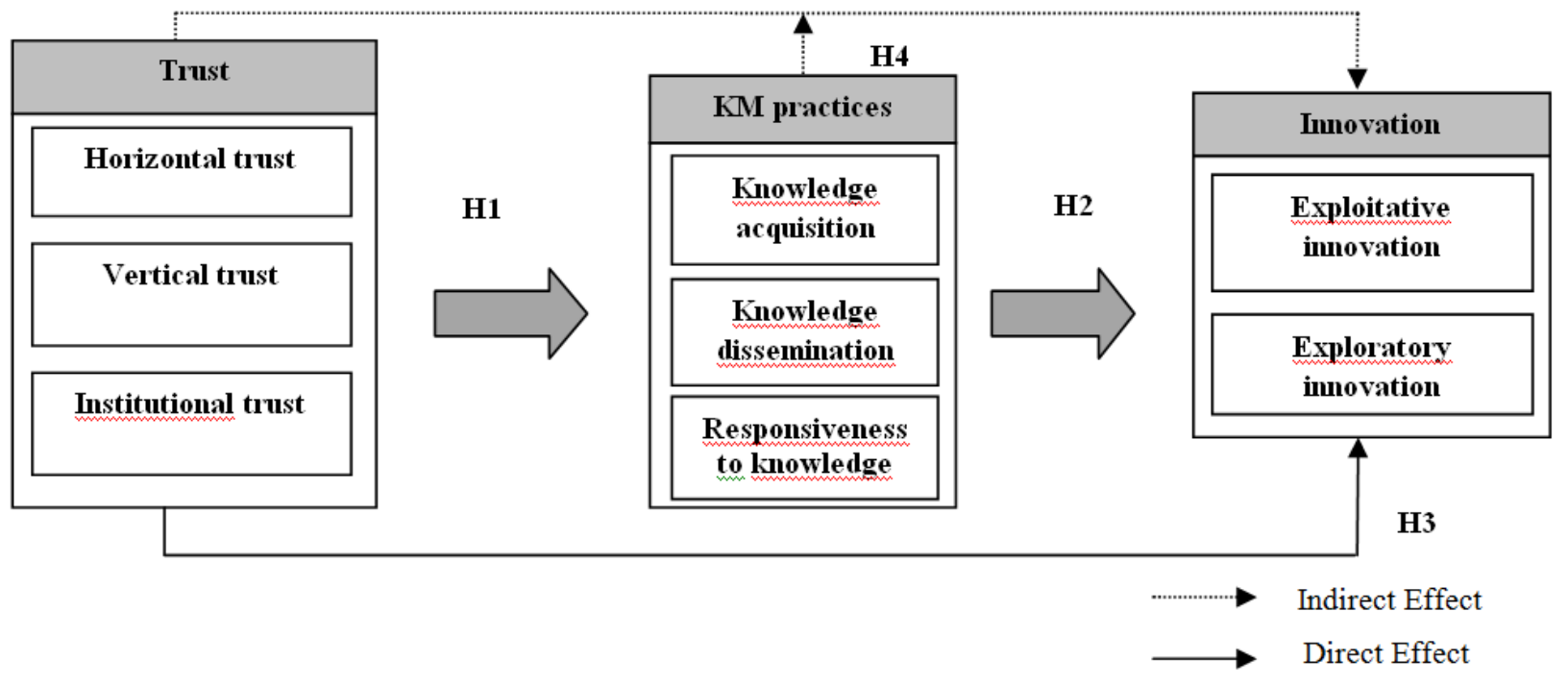




\section{EMPIRICAL STUDY}

\subsection{Survey Procedure and Sample Characteristics}

From a survey of companies operating in the ICT Tunisian sector, we tried to better understand the relationship between interpersonal trust, KM practices and innovation. We have adopted a quantitative approach carried out using a questionnaire administered in paper and electronic forms. As for the respondents, they are executives considered to be informed enough to respond appropriately to our questions. Of the 286 questionnaires distributed among them, 226 ones were returned. The response rate to the questionnaire was nearly $79 \%$.

\subsection{Measuring Instruments and Constructs' Reliability and Validity}

KM practices were operationalized by the scale developed by Darroch (2003). Exploitative and exploratory innovations were measured by the scale proposed by Jansen et al. (2006) (6 items each). Horizontal trust was measured by six items of the scale of Cook \& Wall (1980). Vertical trust (8 items) and institutional trust (4 items) were assessed by the scale designed by Nyhan \& Marlowe (1997). For all items, we used a 5-point Likert scale format (1: strongly disagree and 5: strongly agree).

The collected data were processed by an exploratory analysis using SPSS 16 software. Dimensionality of the scales was tested by subjecting the items to a principal component analysis with a varimax rotation. Items with low factor loadings were removed. Cronbach's alpha was then calculated to test the internal reliability of the construct and was considered acceptable at the threshold of 0.7 (Nunnally, 1978) (Table 1).

Confirmatory factor analysis was next conducted using the AMOS 16.0 software and corroborated the factor structures emerged from the exploratory analysis. We tested the models fit for each variable. Fit indices were found compliant to the critical acceptance thresholds. Moreover, since dimensions of each KM practices are highly correlated, we performed tests of second-order models which presented evidence of satisfactory fit. To test the model of our research, we have adopted this second order structure for 'knowledge acquisition', 'knowledge dissemination' and 'responsiveness for knowledge'. We also calculated the Jöreskog's Rhos of each construct, which exceeded the cut-off value of 0.7 for all constructs and show thus a good composite reliability. The final structure of constructs is presented in Table 1.

Table 1. Dimensionality and Reliablity of Constructs

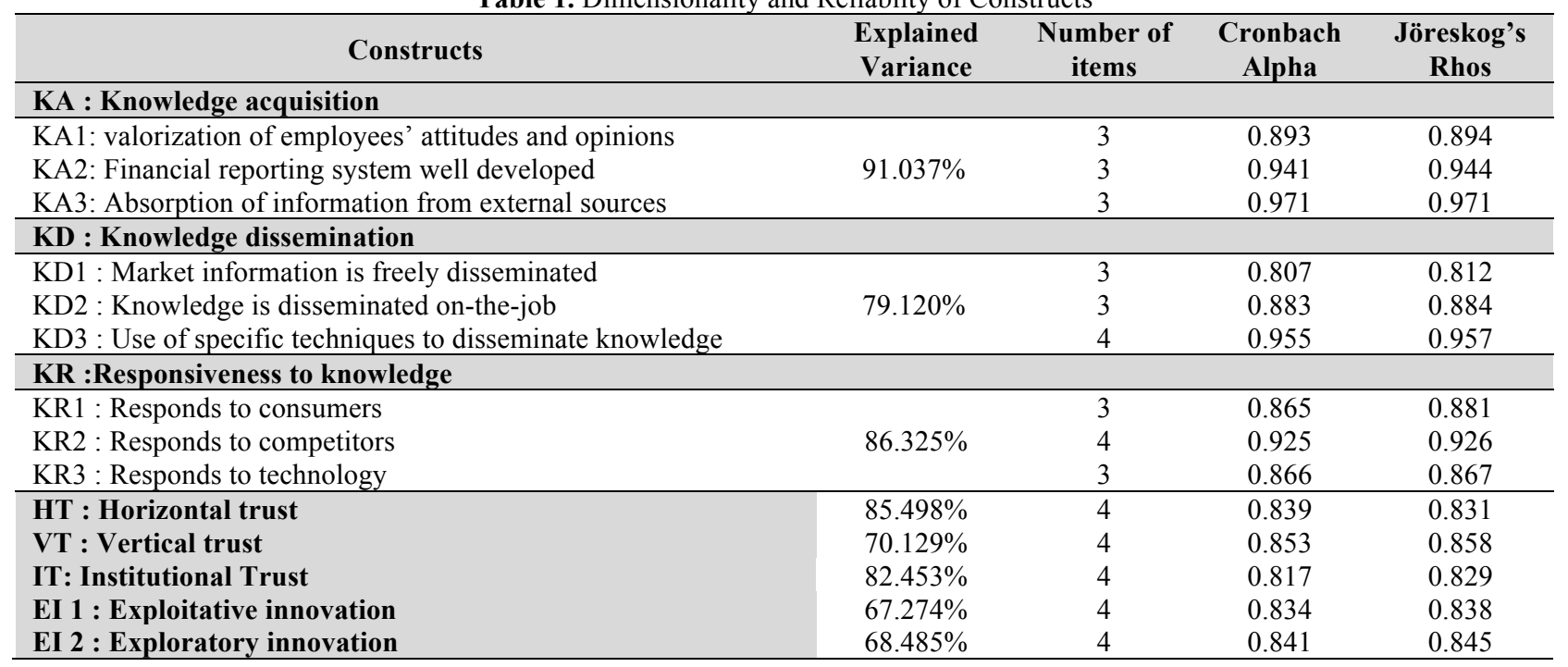


Then, convergent validity was evaluated by examining the average variance extracted (AVE) for each constructs (on the diagonal of Table 2), which exceeded 0.5 as suggested by Fornell \& Larcker (1981). Based on the recommendations of these authors (1981), we also checked constructs' discriminate validity ensuring that the AVE of each construct is greater than the squared correlations with each other construct.

Table 2. Convergent and discriminant validity of constructs

\begin{tabular}{|c|c|c|c|c|c|c|c|c|c|c|c|c|c|c|}
\hline & KA1 & KA2 & KA3 & KD1 & KD2 & KD3 & KR1 & KR2 & KR3 & HT & VT & IT & EI 1 & EI 2 \\
\hline KA1 & 0.739 & & & & & & & & & & & & & \\
\hline KA2 & 0.327 & 0.849 & & & & & & & & & & & & \\
\hline KA3 & 0.314 & 0.479 & 0.918 & & & & & & & & & & & \\
\hline KD1 & 0.234 & 0.217 & 0.195 & 0.525 & & & & & & & & & & \\
\hline KD2 & 0.179 & 0.176 & 0.213 & 0.441 & 0.718 & & & & & & & & & \\
\hline KD3 & 0.103 & 0.129 & 0.078 & 0.335 & 0.364 & 0.883 & & & & & & & & \\
\hline KR1 & 0.185 & 0.257 & 0.336 & 0.126 & 0.033 & 0.112 & 0.716 & & & & & & & \\
\hline KR2 & 0.073 & 0.086 & 0.236 & 0.233 & 0.419 & 0.066 & 0.493 & 0.686 & & & & & & \\
\hline KR3 & 0.121 & 0.334 & 0.248 & 0.139 & 0.087 & 0.117 & 0.351 & 0.408 & 0.761 & & & & & \\
\hline HT & 0.154 & 0.083 & 0.176 & 0.168 & 0.053 & 0.085 & 0.123 & 0.076 & 0.094 & 0.554 & & & & \\
\hline VT & 0.223 & 0.067 & 0.187 & 0.152 & 0.097 & 0.264 & 0.043 & 0.089 & 0.033 & 0.028 & 0.602 & & & \\
\hline IT & 0.011 & 0.023 & 0.017 & 0.018 & 0.026 & 0.052 & 0.012 & 0.043 & 0.036 & 0.047 & 0.056 & 0.679 & & \\
\hline EI 1 & 0.118 & 0.074 & 0.143 & 0.069 & 0.127 & 0.293 & 0.219 & 0.055 & 0.138 & 0.182 & 0.203 & 0.049 & 0.565 & \\
\hline EI 2 & 0.266 & 0.132 & 0.185 & 0.063 & 0.145 & 0.068 & 0.151 & 0.082 & 0.096 & 0.289 & 0.494 & 0.065 & 0.487 & 0.583 \\
\hline
\end{tabular}

\subsection{Results}

Causality characterizing the conceptual model has been tested by a structural equations modeling and using the maximum likelihood method through the AMOS 16.0 software. The mediating effects were tested in the context of the four-step method of Baron \& Kenny (1986). In the first two steps, we must confirm a significant direct relationship between the independent and the dependent variables and a significant relationship between the independent variable and the mediating variable. The third step aims to show that the mediating variable affects the dependent variable in the model incorporating all the variables. If these three conditions are satisfied, then we can confirm mediation. Concretely, when mediation is complete, the regression coefficient linking the independent variable and the dependent variables should be zero under the effect of the mediating variable. The Sobel test is used also to confirm the significance of the mediating effect.

The fit indices of the global model were satisfactory compared against the thresholds recommended by Chin \& Todd (1995) and Hu \& Bentler (1999). Indeed, the Chi-square value to degrees of freedom is 1.363 and is lower than the threshold of 2.5. The GFI (0.994), AGFI (0.969), NFI (0.981) and CFI (0.998) exceeded the cut-off of 0.9 . The RMSEA index is 0.041 and is inferior to the threshold of 0.08 .

The estimated regression coefficients and their significance were then used to check for the relationships between the variables (Table 3). First, results indicate that acquisition and dissemination of knowledge are positively influenced by both horizontal and vertical trust. These findings corroborate the work of Davenport \& Prusak (1998) and Probst et al. (2000) but they are not consistent with the work of Hoe \& McShane (2002) which found nonsignificant results between interpersonal trust and dissemination of knowledge from an empirical investigation conducted on ICT Singapore companies. In addition, significant causal relationships emerged between horizontal and vertical trusts and responsiveness for knowledge. These findings corroborate the work of Holste \& Fields (2010). Therefore, Hypotheses $1 \mathrm{a}$ and $1 \mathrm{~b}$ are confirmed. Our data showed also that institutional trust is not significantly correlated to the three KM practices. Our result is not consistent with the work of Bugdol and Jedyna (2015) and Ford (2003). Henceforth, hypothesis 1c is rejected.

Moreover, results point out that the three KM practices are positively correlated with both exploitative innovation and exploratory innovation. Hypothesis 2 is therefore confirmed. The more people will trust their colleagues and their superiors, the more they contribute to the innovation of their companies. These results support the work of Darroch (2005) and in part the study of Kitapci et al. (2012). Indeed, the results concerning the causal 
relationships between knowledge dissemination and the two types of innovation are inconsistent with the work of these authors, who found non-significant relationships between these variables in an empirical study conducted in Turkey.

Then, results allow us to confirm that horizontal trust and vertical trust have positive and significant effects on both exploitative innovation and exploratory innovation. This finding is consistent with the work of Ellonen et al. (2008) and Golipour et al. (2011), for whom interpersonal trust is a determinant of innovation. Hence, hypotheses 3a and $3 \mathrm{~b}$ are confirmed. Moreover, findings point out that institutional trust is not significantly related to the two types of innovation. This result does not coincide with the work of Ellonen et al. (2008) and Semerciöz et al. (2011). Hypothesis $3 \mathrm{c}$ is thus rejected.

\begin{tabular}{|c|c|c|c|c|}
\hline Independent variable & Dependent variable & $\boldsymbol{\beta}$ & C.R. & $\mathbf{P}$ \\
\hline \multirow{5}{*}{$\begin{array}{l}\text { Horizontal } \\
\text { trust }\end{array}$} & Exploitative innovation & 0.552 & 5.735 & $* * *$ \\
\hline & Exploratory innovation & 0.699 & 7.866 & $* * *$ \\
\hline & Knowledge acquisition & 0.398 & 4.602 & $* * *$ \\
\hline & Knowledge dissemination & 0.285 & 3.613 & $* * *$ \\
\hline & Responsiveness to knowledge & 0.202 & 2.767 & $* * *$ \\
\hline \multirow{5}{*}{$\begin{array}{l}\text { Vertical } \\
\text { trust }\end{array}$} & Exploitative innovation & 0.597 & 6.036 & $* * *$ \\
\hline & Exploratory innovation & 0.796 & 8.439 & $* * *$ \\
\hline & Knowledge acquisition & 0.659 & 7.420 & $* * *$ \\
\hline & Knowledge dissemination & 0.543 & 6.957 & $* * *$ \\
\hline & Responsiveness to knowledge & 0.174 & 2.528 & $* * *$ \\
\hline \multirow{4}{*}{$\begin{array}{l}\text { Institutional } \\
\text { trust }\end{array}$} & Exploitative innovation & 0.115 & 1.393 & 0.167 \\
\hline & Exploratory innovation & 0.102 & 1.526 & 0.125 \\
\hline & Knowledge acquisition & 0.045 & 0.632 & 0.441 \\
\hline & Responsiveness to knowledge & 0.129 & 1.667 & 0.093 \\
\hline \multirow{2}{*}{$\begin{array}{l}\text { Knowledge } \\
\text { acquisition }\end{array}$} & Exploitative innovation & 0.343 & 3.820 & $* * *$ \\
\hline & Exploratory innovation & 0.588 & 6.340 & $* * *$ \\
\hline \multirow{2}{*}{ Knowledge dissemination } & Exploitative innovation & 0.474 & 4.734 & $* * *$ \\
\hline & Exploratory innovation & 0.253 & 2.695 & $* * *$ \\
\hline \multirow{2}{*}{ Responsiveness to knowledge } & Exploitative innovation & 0.494 & 5.247 & $* * *$ \\
\hline & Exploratory innovation & 0.216 & 2.791 & $* * *$ \\
\hline
\end{tabular}

$\beta$ : standardized regression coefficient, C.R. : critical ratio, $* * *:$ P-value $(\mathrm{P})<0.001$

Moreover, regarding the mediation test of the KM practices in the institutional trust-types of innovation relationship, the first three conditions of Baron and Kenny (1986) were not successful. Hypotheses 4c is therefore rejected. However, the mediation test was conclusive for the three mediating variables in case of the relationship between the horizontal trust respectively vertical trust and the two types of innovation as recommended by Baron and Kenny (1986). In addition, standardized regression coefficients testing the indirect effects between each independent variable (horizontal and vertical trust) and each dependent variable (exploratory and exploitative innovation) are significant but lower than the standardized regression coefficients testing the direct relationship between these variables (Table 4). Hence, the three KM practices partially mediate the relationship between horizontal trust respectively vertical trust and the types of innovation. Next, we conducted the Sobel test which confirms the significance of the mediating effects. Hypotheses $4 \mathrm{a}$ and $4 \mathrm{~b}$ are therefore confirmed. 
Table 4. Significance Test Of Mediating Effects

\begin{tabular}{|c|c|c|c|c|}
\hline & & \multirow{2}{*}{ Indirect effect } & \multicolumn{2}{|c|}{ Test de Sobel } \\
\hline & & & $\mathbf{Z}$ & $\mathbf{p}$ \\
\hline \multicolumn{5}{|c|}{ Horizontal trust and exploitative innovation $($ direct effect $=0.552)$} \\
\hline & Knowledge acquisition & 0.136 & 2.783 & ** \\
\hline Mediating & Knowledge dissemination & 0.135 & 2.396 & $*$ \\
\hline variables & Responsiveness to knowledge & 0.099 & 2.820 & ** \\
\hline \multicolumn{5}{|c|}{ Total indirect effect $=0.37$} \\
\hline \multicolumn{5}{|c|}{ Horizontal trust and exploratory innovation $($ direct effect $=0.699)$} \\
\hline & Knowledge acquisition & 0.234 & 3.783 & $* * *$ \\
\hline Mediating & Knowledge dissemination & 0.072 & 1.993 & $*$ \\
\hline variables & Responsiveness to knowledge & 0.043 & 2.162 & * \\
\hline \multicolumn{5}{|c|}{ Total indirect effect $=0.349$} \\
\hline \multicolumn{5}{|c|}{ Vertical trust and exploitative innovation $($ direct effect $=0.597)$} \\
\hline & Knowledge acquisition & 0.226 & 3.446 & $* * *$ \\
\hline Mediating & Knowledge dissemination & 0.257 & 4.843 & $* * *$ \\
\hline variables & Responsiveness to knowledge & 0.085 & 2.126 & $*$ \\
\hline \multicolumn{5}{|c|}{ Total indirect effect $=0.568$} \\
\hline \multicolumn{5}{|c|}{ Vertical trust and exploratory innovation $($ direct effect $=0.796)$} \\
\hline & Knowledge acquisition & 0.387 & 4,809 & $* * *$ \\
\hline Mediating & Knowledge dissemination & 0.137 & 2.975 & $* *$ \\
\hline variables & Responsiveness to knowledge & 0.037 & 2.154 & $*$ \\
\hline \multicolumn{5}{|c|}{ Total indirect effect $=0.561$} \\
\hline
\end{tabular}

*: P-value $(\mathrm{P})<0.05, * *$ : P-value $(\mathrm{P})<0.01 ; * * *$ : P-value $(\mathrm{P})<0.001$

Therefore, KM practices are the seeds of innovation. They allow companies to absorb and integrate continuous strategic knowledge especially on the opportunities, threats, latest developments in technology, innovations introduced by their competitors and the needs of their customers. Further, the implementation of KM practices, namely knowledge acquisition, knowledge dissemination and responsiveness for knowledge has resulted in the generation of both exploitative and exploratory innovations. The role of KM as a source of innovation is particularly optimized through interpersonal trust. Indeed, success of KM practices depends, among other things, on trust between employees and trust between employees and their supervisors. This finding confirms the work of Hutchings \& Weir (2005) who found that in Arab countries such as Tunisia, interpersonal trust is a key factor for the success of KM. However, our results show that institutional trust does not affects KM practices and innovation. Therefore, trustful personal contacts between organizational members are the key for boosting KM practices and innovation in the case of ICT Tunisian companies.

\section{CONCLUSION}

Empirical research conducted on a sample of ICT Tunisian firms allowed us to highlight the role of KM practices, particularly knowledge acquisition, knowledge dissemination and responsiveness for knowledge, as drivers of innovation. In the context of knowledge economy, the key success factors for companies are nowadays based on continuous process of innovation fructified thanks to the continued development and enhancement of knowledge capital. The results of our empirical study regarding the relationship between KM practices and innovation converge with research operated in culturally different contexts especially in Japan (Nonaka \& Takeuchi, 1995), New Zealand (Darroch, 2005), Europe (Ramirez \& Kumpikaite, 2012) and Iran (Allameh \& Abbas, 2010). This relationship is particularly reinforced by trust that employees develop within the organization especially towards their colleagues and their supervisors. Indeed, this study highlighted the importance of trustful interpersonal connections between organizational members in paving the way for a better implementation of KM practices and in strengthening their role as an innovation catalyst for ICT companies. This research also confirmed the importance of interpersonal trust for the success of KM practices and as a factor strengthening the ability of businesses to generate both exploitative and explorative innovation

This research made a significant contribution at the theoretical level in the sense that it provides a better understanding of the relationship between different types of trust, KM practices and two types of innovation. Managers may use this study to develop and strengthen KM practices as operationalized by the different items used 
in this research. In this context, we suggest that companies should build dashboards of their knowledge to assess the performance of the KM approach. Indeed, KM is of a paramount importance nowadays for those companies facing increased competition and development of new technologies. It must be a part of a forward-looking perspective of prevention against the risk of loss of knowledge and skills and as an approach seeking deposits of value creation for companies. Managers should also create an atmosphere of trust and knowledge sharing within the organization.

This study allowed us to determine the partial mediating role of KM practices in the relationship between interpersonal trust and innovation. Thus, KM practices are not the only mediating variables in the tested model. Other mediating and / or moderating variables could be incorporated to our model. Indeed, in continuity of this work, it would be appropriate to include other variables such as employees' empowerment and commitment to the organization allowing a deepening of the relationship between interpersonal trust and innovation. Methodologically and empirically, the development of a qualitative research to examine in depth this research problem stands as a relevant perspective that could improve this study. Finally, researchers may extend this study to other sectors or may conduct a cross-cultural comparative study.

\section{AUTHOR INFORMATION}

Sarra Berraies, Ph.D. in Management Sciences from the Higher Institute of Management of Tunis, Assistant professor at the Higher Institute of Management and Computer Science of Kairouan, I teach management, marketing, accounting and finance. My research interests include Knowledge Management, Innovation, Learning, Strategic Management of Entreprises, Human Resources Management... I published extensively in academic journals and participated in several international conferences such as International Business Information Management Association (IBIMA), International Conference on Business research and International Marketing Trends Conference. E-mail: sarraberraies610@yahoo.fr

Maha Achour, $\mathrm{PhD}$ in Quantitative Methods from the Higher Institute of Management of Tunis and Assistant Professor at the Higher Institute of Computer Sciences and Management of Kairouan. My research areas include applied econometrics, data analysis, time series modeling and forecasting, applied statistics, etc. I published in academic journals and participated to several international conferences such as European Economic Association Conference, International Conference of Finance, and Middle East Economic Association Conference. E-mail: maha_achour_isg@yahoo.fr

Mehrez Chaher, Ph.D. in Management Sciences and Professor of Strategic Management at the University of Tunis. Former Director of the Higher Institute of Management of Tunis. Coordinator of the Research Master "Administration and Business Strategy" at the Higher Institute of Management of Tunis and a founding member of the research laboratory "ARBRE", UNIDO International Consultant, Author and co-author of twenty publications on strategic management of enterprises, skills development, sustainable development and Corporate social responsibility of Tunisian companies. Director and co-director of thirty doctoral theses, President of the Tunisian Association of Strategic Intelligence (ATIS).

\section{REFERENCES}

Abrams, L.C., Cross, R., Lesser, E. \& Levin, D.Z. (2003). Nurturing interpersonal trust in knowledge-sharing networks. The Academy of Management Executive, 17(4), 64-77.

Allameh, S.M. \& Abbas, S.K. (2010). The Relationship between Knowledge Management Practices And Innovation Level In Organizations: Case Study of Sub Companies of Selected Corporations in the City of Esfahan. Journal of Business Case Studies, 6(1), 89-98.

Baron, R.M. \& Kenny, D.A. (1986). The Moderator-Mediator Variable Distinction in Social Psychological Research: Conceptual, Strategic, and Statistical Considerations. Journal of Penality and Social Psychology, 51(6), 11731182.

Bassie, L.J. (1997). Harnessing the power of intellectual capital. Training and Development, 51(12), 25-30.

Benner, M. \& Tushman, M. (2003). Exploitation, exploration and process management: the productivity dilemma revisited. Academy of Management Review, 28(2), 238-256.

Berraies, S. (2012). Le rôle de la gestion des connaissances dans le développement de l'innovation. Doctoral dissertation, Higher Institute of Management of Tunis, Tunisia.

Copyright by author(s); CC-BY 
Budgol, M. \& Jedynak, P. (2015). Integrated Management Systems. Springer international Publishing, Switzerland. Chanal, V. \& Mothe, C. (2005). Concilier innovations d'exploitation et d'exploration: le cas du secteur automobile. Revue Française De Gestion. 154(1), 173-191.

Chin, W.W. \& Todd, P.A. (1995). On the Use, Usefulness, and Ease of Use of Structural Equation Modeling in MIS Research: A Note of Caution. MIS Quarterly. 19(2), 237-246.

Chandler, G.N., Keller, C. \& Lyon, D.W. (2000). Unraveling the determinants and consequences of an innovativesupportive organizational culture. Entrepreneurship Theory and Practice. 25(1), 59-76.

Chouk, I. \& Perrien, J. (2003). Les déterminants de la confiance du consommateur lors d'un achat sur un site marchand : proposition d'un cadre conceptuel préliminaire. 19th International Congress of Frensh Association of Marketing in Tunisia, 581-593.

Clegg, C., Unsworth, K., Epitropaki, O. \& Parker, G. (2002). Implicating trust in the innovation process. Journal of Occupational and Organizational Psychology, 75(4), 409-422.

Cook, J. \& Wall, T. (1980). New Work Attitude Measures of Trust, Organizational Commitment and Personal Need NonFulfilment. Journal of Occupational Psychology, 53(1), 39-52.

Darroch, J. (2003). Developing a measure of knowledge management behaviors and practices. Journal of knowledge management, 7(5), 41-54.

Darroch, J. (2005). Knowledge management, innovation and firm performance. Journal of Knowledge Management, 9(3), 101-115.

Davenport, T.H. (1994). Saving IT's Soul: Human Centered Information Management. Harvard Business Review, MarchApril, 72(2), 119-131.

Davenport, T.H., \& Prusak, L. (1998). Working knowledge: How organizations manage what they know. Harvard Business School Press, Boston.

Deroy, X. (2004). L’innovation contingente, deux sagas: Zodiac et Salomon. Futuribles, 22, 3-76.

Dovey, K. (2009). The role of trust in innovation. The Learning Organization, 16(4), 311-325.

Drucker, P.F. (1985). Innovation and Entrepreneurship: Practice and Principle, Harper \& Row, New York.

Ellonen, R., Blomqvist, K. \& Puumalainen, K. (2008). The role of Trust in organizational innovativeness. European Journal of Innovation Management, 11(2), 160-181.

Ford, D.P. (2003). Trust and Knowledge Management: The Seeds of innovation. In: Handbook on Knowledge Management Holsapple Cw (ed), 553-576. Springer-Verlag, Berlin, Heidelberg.

Fornell, C. \& Larker, D.F. (1981). Evaluating Structural Equations Models with Unobservable Variables and Measurement Error. Journal of Marketing Research, 18(1), 39-50.

Gibson, C.B., \& Birkinshaw, J. 2004. The antecedents, consequences, and mediating role of organizational ambidexterity. Academy of Management Journal, 47(2), 209-226.

Golipour, R., Ghoplamreza, J., Mirzaei, M.A. \& Roshandel Arbantan, T. (2011). The impact of organizational trust on innovativeness at the Tehran oil refinery company. African Journal of business Management, 5(7), 2660-2667.

Hoe, S.L., \& McShane, S.L. (2002). Leadership Antecedents of Informal Knowledge Acquisition and Dissemination. International Journal of Organisational Behaviour, 5(10), 282-291.

Holste, J.S. \& Fields, D. (2010). Trust and tacit knowledge sharing and use. Journal of Knowledge Management, 14(1), 128-140.

Hu, L.T. \& Bentler, P.M. (1999). Cutoff Criteria for Fit Indexes in Covariance Structure Analysis: Conventional Criteria versus New Alternatives. Structural Equation Modeling. 6(1), 1-55.

Hutchings, K. \& Weir, D. (2005). Cultural Embeddedness and Contextual Constraints: Knowledge Sharing in Chinese and Arab Cultures. Knowledge and Process Management, 12(2), 89-98.

Jansen, J.J.P., Van Den Bosch, F.A.J. \& Volberda, H.W. (2006). Exploratory Innovation, Exploitative Innovation, and Performance Effects of Organizational Antecedents and Environmental Moderators. Management Science, 52(11), 1661-1674.

Kitapci, H., Aydin, B. \& Celik, V. (2012). The effects of organizational learning capacity and innovativeness on financial performance: An empirical study. African Journal of Business Management, 6(6), 2332-2341.

Kline, L. \& Rosenberg, N. (1986). An Overview of Innovation' In R. Landau and N. Rosenberg (eds) The Positive Sum Strategy: Harnessing Technology for Economic Growth, Washington D.C.: National Academy Press, 275-304.

Lamari, M. (2010). Le transfert intergénérationnel des connaissances tacites : les concepts utilisés et les évidences empiriques démontrés. Telescope, 16(1), 39-65.

Lee, H. \& Choi, B. (2003). Knowledge Management Enablers, Processes, and Organizational Performance: An Integrative View and Empirical Examination. Journal of Management Information System. 20(1), 179-228.

Lee, K.C., Lee, S., \& Kang, IW. (2004), 'KMPI: Measuring Knowledge Management Performance', Information and Management, 42 (2005), 469-482.

March, J.G. (1991). Exploration and exploitation in organizational learning. Organization Science, 2(1), 71-87. 
Mayer, R.C., Davis, JH., \& Schoorman, FD. (1995). An Integrative Model of Organizational Trust. Academy of Management Review, 20(3), 709-734.

McAllister, D.J. (1995). Affect and cognition-based trust as foundations for interpersonal cooperation in organizations. Academy of Management Journal, 38(1), 24-59.

Marais, A. \& Hofmeyr, K. (2013). Corporate restructuring: does damage to institutional trust affect employee engagement?. South African Journal of Labour Relations, 37(2), 9-29.

Martinet, A.C. (2003). Stratégie et Innovation', In P. Mustar, et H. Penan, (2003), Encyclopédie de l'Innovation, Economica Edition, Paris, 29-48.

Martinez, M.N. (1998). The Collective Power of Employee Knowledge”. HR Magazine, 43(2), 88-94.

Miller, W.L. \& Morris, L. (1999). Fourth Generation R\&D: Managing Knowledge, Technology and innovation, John Wiley \& Sons, New York.

Morgan, R. \& Hunt, S. (1994). The Commitment-Trust Theory of Relationship Marketing. Journal of Marketing, 58(3), 20-38.

Naidoo, V. (2010). Firm Survival through a Crisis: The Influence of Market Orientation, Marketing Innovation and Business Strategy. Industrial Marketing Management, 39(8), 1311-1320.

Nemani, R.R. (2010). The role of Computer Technologies in Knowledge Acquisition. Journal of Knowledge Management Practice, 11(3).

Ngah, R., Hoo, H.C. \& Ibrahim, AR. (2008). The Relationship between Knowledge Management and Trust: Malaysian Perspective. Communications of the IBIMA, 4(14), 113-119.

Nonaka, I. (1991). The knowledge-creating company. Harvard Business Review, 69, November-December, 96-104.

Nonaka, I. \& Takeuchi, H. (1995). The Knowledge-creating Company, Oxford University Press, New York.

Nonaka, I., Toyama, R. \& Konno, N. (2000). SECI, Ba and Leadership: A Unified Model of Dynamic Knowledge Creation. Long Range Planning. 33(1), 5-34.

Nunnally, J.C. (1978). Psychometrie theory. New York: McGraw-Hill.

Nyhan, R.C. \& Marlowe, HA. (1997). Development and Psychometric Properties of the Organizational Trust Inventory. Evaluation Review, 21(5), 614-635.

Porter, M. (1986). L'avantage concurrentiel, InterEdition, Paris.

Pöyhönen, A. \& Blomqvist, K. (2006). Knowledge-Based View of the Firm _ Foundations, Focal Concepts and Emerging Research Issues. Proceedings of the 7th European Conference on Knowledge Management, Budapest: 425-433.

Probst, G., Raub, S. \& Romhardt, K. (2000). Managing Knowledge, John Wiley \& Sons, Chichester.

Ramirez, A.M. \& Kumpikaite, V. (2012). Creation, Transfer and Application of Knowledge and its Importance for Business Innovation and Organizational Performance. International Proceedings of Economics Development \& Research. 46(6), 27-31.

Ribière, V.M. \& Tuggle, FD. (2005). The Role of Organizational Trust in Knowledge Management: Tools \& Technology Use \& Success. International Journal of Knowledge Management, 5(4), 468-491.

Robinson, S.L. (1996). Trust and breach of the psychological contract. Administrative Science Quarterly, 41(4), 574-599.

Rousseau, D., Sitkin, S., Burt, R. \& Camerer, C. (1998). Introduction to special topic forum. Not so different after all: A cross-discipline view of trust,' Academy of Management Review, 23(4), 393-404.

Sankowska, A. (2013). Relationships between Organizational Trust, Knowledge Transfer, Knowledge Creation and Firm's Innovativeness. Learning Organization, 20(1), 85-100.

Schulze, A. \& Hoegl, M. (2008). Organizational Knowledge Creation and the Generation of New Product Ideas: A behavioral approach. Research Policy, 37(10), 1742-1750.

Schumpeter, J.A. (1982). The Theory of Economic Development, Harvard University Press, Cambridge.

Semerciöz, F., Hassan, M. \& Aldemır, Z. (2011). An Empirical Study on the Role of Interpersonal and Institutional Trust in Organizational Innovativeness. International Business Research, 4(2), 125-136.

Szulanski, G. (1995). Unpacking stickiness: an empirical investigation of the barriers to transfer best practices in the firm. Academy of Management Journal, Best Papers Proceedings, 38(special issue), 437-441.

Tan, H.H. \& Tan, C.S.F. (2000). Toward a differentiation of trust in supervisor and trust in organization. Genetic, Social and General Psychology Monographs. 126(2), 241-60.

Tsai, W. \& Ghoshal, S. (1998). Social capital and value creation: The role of intra-firm networks. Academy of Management Journal, 41, 464-476.

Upadhayayula, R.S. \& Kumar, R. (2004). Social capital as an antecedant of absorptive capacity of firms. Proceeding of DRUID Conference, 14-16 June 2004, Danemark. 


\section{NOTES}

